\title{
Reading the Gospel of MattheW Within the global ConteXt: A RESPONSE
}

Author:

Elaine M. Wainwright ${ }^{1,2}$

Affiliations:

${ }^{1}$ School of Theology

University of Auckland,

New Zealand

${ }^{2}$ Department of New

Testament Studies,

Faculty of Theology,

University of Pretoria,

South Africa

Correspondence to:

Elaine M. Wainwright

e-mail:

em.wainwright@auckland.

ac.nz

\section{Postal address:}

School of Theology,

University of Auckland,

Private Bag 92019

Auckland, New Zealand

\section{Keywords:}

Gospel of Matthew;

Society of Biblical

Literature; hermeneutics;

Matthean texts; Biblical

interpretation in a global

context

Dates:

Received: 24 Apr. 2009

Accepted: 06 July 2009

Published: 11 Nov. 2009

How to cite this article: Wainwright, E.M

'Reading the Gospel of

Matthew within the global

context: A response',

HTS Teologiese Studies/

Theological Studies 65(1),

Art. \#322, 2 pages. DOI:

10.4102/hts.v65i1.322

\section{This article is available}

at:

http://www.hts.org.za

Note:

Prof. Dr Elaine M.

Wainwright participates

in the research project

'Biblical Theology and

Hermeneutics', directed

by Prof. Dr Andries G.

van Aarde, Honorary

Professor of the Faculty of

Theology at the University of Pretoria.

\section{(c) 2009. The Authors.}

Licensee: OpenJournals

Publishing. This work

is licensed under the

Creative Commons

Attribution License.

\section{ABSTRACT}

This article responds to the diversity of approaches in the five papers presented at the Matthew Section of the Society of Biblical Literature, held in Boston (Massachusetts), 21-25 November 2008. This response focuses on an overarching question: what does it mean to read Matthew in a global context? It considers two key areas. The first is location and voice/language and the second, the hermeneutics and methodologies employed and how these enabled John Y.H. Yieh (Virginia Theological Seminary), Andries van Aarde (University of Pretoria), Dorothy Jean Weaver (Eastern Mennonite Seminary), Laura Anderson (Graduate Theological Union, Berkeley) and Lidija Novakovic (Baylor University, Waco) to read Matthew within a global context.

\section{INTRODUCTION}

Thank you very much to the Committee for the Matthew Section for this invitation to respond to a diverse range of very well-conceived papers from John Yieh, Andries van Aarde, Dorothy Jean Weaver, Laura Anderson and Lidija Novakovic.

The key question and issue that this session raises is: How might we read Matthew within a global context? Perhaps at no other time are we more in need of good news, of an alternate vision, than we are at this time of global financial crisis despite the historic moment in United States and world politics that occurred on 4 November 2008 with the election of President Barack Obama. As the first African American to hold the office of president of one of the world's most influential nations and with his proven commitment to justice and human rights, he offers hope to a world faced with profound issues. I want to acknowledge this moment as it will have a global impact both symbolically as well as actually.

There are many other issues that constitute the global among the complexities of our world: almost every part of the Middle East remains a political flashpoint; inflation and therefore poverty in Zimbabwe are at a level beyond comprehension; the Congo and almost every country of central, east and west Africa face political and economic crises; and the islands of one of the most forgotten areas of the world, Oceania, face not only political upheaval but the potential of the very loss of their island homes as global warming is fuelled by the developed and developing nations and regions.

These are but a few of the multiple issues that constitute the global context in which we are invited to read the Gospel of Matthew.

In order to respond to the diversity of approaches in each of the papers in the context of the overarching question - what does it mean to read Matthew in a global context - I found myself considering two key areas. The first is location and voice/language and the second, hermeneutics and methodologies employed and how these enabled Yieh, Van Aarde, Weaver, Anderson and Novakovic to read Matthew within a global context.

\section{LOCATION AND VOICE/LANGUAGE}

The word 'global' is a challenging one. Some of its synonyms are 'worldwide', 'international', 'universal', 'comprehensive' and 'inclusive'. Does global mean that readers have a global focus or is it seeking to hear as wide a range of voices as possible? Whose voices will we hear, can we hear? And from where do those voices rise up? And a related question is that of language - in what language will we or can we hear the global voices?

When I examined the location of the presenters, four of the five are at least currently located in the United States and Van Aarde is from South Africa. Of the respondents, Daniel Ulrich too is located in the United States and I am from Oceania; by birth from the largest island/continent in that region, Australia, and currently resident in the second largest, New Zealand. From whose location do we read globally and if this means from multiple locations, how do we hear the multiple voices? In our part of the world this challenges us to listen for the Maori, the Samoan, Tongan, Fijian, Solomon Island and many other voices from varied contexts that are articulating a reading of Matthew's Gospel. If the feminist catch cry was true (and I believe it was/is) - no woman is free until all women are free - then is it equally so that no global voice is truly heard until all are heard? And the other challenge to us as biblical scholars is - in whose language? Since none of us have multiple lives in which to learn multiple languages, how will we hear the global voices now when international biblical scholars are emerging from every corner of the globe? Do the newest or the remotest have to learn the language of the dominant, more numerical and more powerful? Or are there creative ways in which, in today's world of mass communication, we can indeed hear the many voices speaking in their own tongue/s?

In the group of papers in this section, we heard Yieh's voice introducing us to a segment of the history of interpretation of Matthew that I knew nothing of and to a range of scholars that I had not previously encountered: a Chinese Wirkungsgeschichte ${ }^{1}$ within a limited time frame. He too has drawn our attention

1. The art of reading a text while being conscious of the different ways in which it has been interpreted through history. 
to the 'translating' issue as it existed for the 19th/early 20th century Chinese scholars who had to translate Western biblical scholarship into the Chinese language and its concepts. Now, global reading seeks to hear the insights from contemporary Chinese biblical scholars and readers of Matthew speaking not just to the West but to the global community of readers. If we could read a range of similar papers from many different locations: Japan, Myanmar, Botswana, Nigeria, Fiji, Tonga and many other corners of the globe, this could be one way to begin to read Matthew within a global context. Van Aarde's paper, set in his context of South Africa, focused on the issues of criminality and poverty which are some of the most challenging issues there. His analysis of this location informed his hermeneutical and methodological approach to his reading of Matthew and so location intersected with hermeneutic and methodology. Novakovic engaged with one perspective on the ideology of economic globalisation, namely its promoting of, rather than addressing of, the inequalities between different groups and cultures. She then read selected Matthean texts which challenge 'the conventional distribution of power in hierarchal structures' and so for her also global questions shaped her reading, both in terms of choice of text and hermeneutical lens. For Anderson, her context was contemporary teaching situations in which she seeks to 're-enact Jesus' and she used economic categories which enabled her to see aspects of Jesus's ministry which were not always consistent. For Weaver the global context provided the issue, namely political power, which is the category she uses to read the Matthean text. I was looking for more analysis of what we mean by both 'political' and 'power' and some engagement with contemporary critical scholarship in order to inform the gospel engagement. Weaver's approach, however, was to allow the categories to emerge from the text and so this raises questions of how to engage with our location/s and emerging issues. Does context (global and/or local) give rise to the issues, questions and categories we bring to interpretation (as it does for many liberation or liberative approaches of the past 30 to 40 years of emerging biblical scholarship) or should the text dictate categories which we then bring into dialogue with context; or is it both/and rather than either/or? And one last question I have not dealt with under location, voice and language, and cannot deal with due to a lack of time, is that of whose voices we dialogue with in our papers. There are other questions which my questions may have raised which will hopefully continue to engage Matthean scholars beyond these papers and a session of the Matthean section of the Society of Biblical Literature.

\section{HERMENEUTICS AND METHODOLOGY}

The second area that is always of interest and concern to me in biblical interpretation that takes account of location and contemporary issues is that of hermeneutic or reading perspective, which will often be closely linked to location and to the methodology chosen to shape an engaged reading. Yieh's Wirkungsgeschichte approach raises the issue of the relationship or perhaps the clash between the Christian Bible and Chinese cultures, an issue that is being raised from many cultural contexts, a significant issue to recognise in reading Matthew in a global context. His reading context also enables him to recognise the issue arising from post-colonial contexts, namely that Matthew's gospel imitated the strategies of the empire as well as resisting them.

This aspect captures some of the questions that I found myself bringing to Weaver's very detailed reading of 'political power' in Matthew's narrative, for which I was most grateful. Her narrative approach or 'close reading of the text' as she describes it and her two groups (Roman and Jewish) seemed to yield a seamless garment of a negative portrayal of power in relation to these two groups. I kept looking for a combination of the rhetoric with the social and cultural texture of the Matthean text that would have enabled the reader to test the perspective presented in the text within the imperial context which the text evokes. How does the gospel imitate as well as resist imperial strategies e.g. a lavish lifestyle is presented as a negative aspect of imperial power and yet this is used by Jesus in parables, not necessarily critically? Likewise, the imperial God saves the chosen 'son', Jesus, but not the other children of Bethlehem whose voices cry out in resistance through Rachel's lament. This approach also raises the question of taking account of whose rhetoric we are hearing, especially, for example, in relation to the Jewish leaders.

Van Aarde's post-colonial perspective and his engagement with its theory gave rise to the category of 'anti-societal language'. His context and focus on criminality and poverty shaped his reading of economic anti-societal language. Others might bring questions of gender or of materiality read through a contemporary ecological lens to determine if there is anti-societal language in relation to these contemporary issues.

I found myself bringing similar hermeneutical questions to Anderson's excellent economic reading of selected healing narratives in Matthew, paying attention to the socio-cultural and economic encoding of limited good. She asks: What is exchanged in the economic interaction? This could be extended to serve an ecological reading in that the materiality of the body is central to healing narratives with an initial naming of the material body being replaced by a changed name by the end of the narrative. Multiple hermeneutics can be brought into dialogue around similar stories to demonstrate the multi-dimensional nature of global concerns and contexts so that one voice, one issue, does not drown out another, especially that of the material, of the other-than-human which is crying out for our attention if we are to save our planet, not just its human community.

Novakovic chooses certain Matthean texts which 'challenge the conventional distribution of power in the hierarchical structures', her hermeneutic leading to her choice of texts as did Van Aarde's. The one question I wanted to bring to her study which integrated hermeneutic and methodology well was one I raised earlier in relation to Weaver's study: How do we define power and how might some of the current post-modern studies such as that of Chela Sandoval (Methodologies of the Oppressed) challenge the imposition of a hierarchal model of power which can be re-read into and onto texts and situations? Sandoval suggests that analyses of the performance of power in a more multidimensional horizontal model will provide us with new insights. This may enable us to take account of the inscribing and critique of the imperial in the Gospel of Matthew in relation to the range of issues which our current global context is raising for us as biblical interpreters and as participants in current communities for whom this text functions to create meaning. What are the resources available to us in our inter-disciplinary contexts that will extend our capacity as biblical scholars to read Matthew in a global context? The hermeneutical and methodological questions are numerous and these too can be taken up in our discussion in ways not possible to me in this short response.

In conclusion, my thanks again to John Yieh, Andries van Aarde, Dorothy Jean Weaver, Laura Anderson and Lidija Novakovic who have raised these and many other questions to engage us in the critical issue of reading Matthew (and indeed reading all our sacred stories) in a global context. 